\title{
AUXILIARY ECR HEATING SYSTEM FOR THE GAS DYNAMIC TRAP
}

\author{
A.G. Shalashov ${ }^{1,2}$, E.D. Gospodchikov ${ }^{1,2}$, O.B. Smolyakova ${ }^{1}$, P.A. Bagryansky, \\ V.I. Malygin ${ }^{1}$, M. Thumm ${ }^{4}$ \\ ${ }^{1}$ Institute of Applied Physics of the Russian Academy of Sciences, N.Novgorod, Russia; \\ ${ }^{2}$ Lobachevsky State University of Nizhni Novgorod (UNN), N.Novgorod, Russia; \\ ${ }^{3}$ Budker Institute of Nuclear Physics, Novosibirsk, Russia; \\ ${ }^{4}$ Karlsruhe Institut für Technologie, Karlsruhe, Germany \\ E-mail: egos@appl.sci-nnov.ru
}

\begin{abstract}
Physics aspects of a new system for electron cyclotron resonance heating (ECRH) at the magnetic mirror device Gas Dynamic Trap (GDT, Budker Institute, Novosibirsk) are discussed. This system based on two $400 \mathrm{~kW} / 54.5 \mathrm{GHz}$ gyrotrons is aimed at increasing the electron temperature up to the range $250 \ldots 350 \mathrm{eV}$ for improved confinement. The key issue of the GDT conditions is that conventional ECRH geometries are not accessible. The proposed solution is based on a peculiar effect of radiation trapping in inhomogeneous magnetized plasma. Under specific conditions oblique launch of gyrotron radiation results in right-hand-polarized electromagnetic waves propagating with high $\mathrm{n}_{\|}$in the vicinity of the cyclotron resonance, what provides effective single-pass absorption of the injected microwave power.
\end{abstract}

PACS: 52.50.Sw, 52.35.Hr, 42.25.Gy

\section{INTRODUCTION}

The mirror device Gas Dynamic Trap (GDT) at the Budker Institute of Nuclear Physics in Novosibirsk is proposed as a fusion neutron source to test and validate inner wall components of future thermonuclear fusion reactors [1]. Relative to previous magnetic mirror neutron sources, the GDT facility uses simpler axisymmetric magnets providing about $2 \mathrm{MW} / \mathrm{m}^{2}$ neutron flux. Recent results with high $\beta=0.6$ provide a firm basis for extrapolating to a fusion relevant high-flux neutron source [2]. Another important application of the GDT neutron source is nuclear waste processing based on fusion driven burning of minor actinides. In this paper we discuss physics and design of a new system for electron cyclotron resonance heating $(\mathrm{ECRH})$ presently under construction for the GDT device which is aimed at increasing the bulk electron temperature in the trap volume and in the long run the efficiency of the neutron source.

The main part of the GDT setup is an axially symmetric magnetic mirror with high mirror ratio. The confined plasma consists of two ion components: the background ions with a temperature of about $200 \mathrm{eV}$ and density $2 \cdot 10^{19} \mathrm{~m}^{-3}$ confined in a gas-dynamic regime, and the hot ions, which are produced as a result of oblique injection of high-power (up to $5 \mathrm{MW}$ ) hydrogen or deuterium beams into the plasma. The distribution function of the hot component is essentially anisotropic in the velocity space; therefore the density and pressure of hot ions are peaked in the mirror (turning) points providing the conditions for fusion reactions. Presently the mean energy of the hot ions is about $9 \mathrm{keV}$, and their density near the mirror points reaches $5 \cdot 10^{19} \mathrm{~m}^{-3}$. Energy confinement times of hot ions as well as their velocity spread are determined basically by the collisional slowing-down on the bulk electrons. Since the collisional time $\tau_{e i} \propto T_{e}^{3 / 2}$, the electron drag force is rapidly decreasing with increasing electron temperature. This makes the electron temperature to be the most important parameter which determines the efficiency of the neutron source.
One of the possibilities to increase the electron temperature in the GDT is provided by the auxiliary ECRH system discussed in the present paper. This system based on two $400 \mathrm{~kW} / 54.5 \mathrm{GHz}$ gyrotrons has a pulse duration close to the typical NBI-driven discharge (about $5 \mathrm{~ms}$ ). The evident and attractive feature of ECRH is direct power transfer into the electron component which may be comparable to the power transmitted to electrons due to the ion slowing-down $(\approx 1 \mathrm{MW})$. Power balance analysis shows that the auxiliary ECRH can provide essential enhancement of electron temperature: up to $350 \mathrm{eV}$ (in case of full absorption) instead of $200 \mathrm{eV}$ achieved in present-day experiments with $5 \mathrm{MW}$ NBI heating. This corresponds to enhancement of the hot-ion confinement time from 2.3 to $5 \mathrm{~ms}$ which drastically increases the efficiency of neutron-flux production.

\section{BASIC PHYSICS OF ECRH IN GDT}

The key physical issue of the GDT conditions is that all conventionally used ECRH geometries are not accessible. The so-called transverse launch of the gyrotron radiation with respect to the ambient magnetic field shows low efficiency for GDT plasmas even at the fundamental harmonic due to reatively low electron temperature and small scales of a device. Indeed, the total optical depth for the ordinary $(\mathrm{O})$ mode may be estimated as [3]

$$
\tau^{\mathrm{O} \text {-mode }}=\int 2 \operatorname{Im} \mathbf{k} \cdot d \mathbf{l} \approx \pi \beta_{e}^{2} q k L_{B}<<1,
$$

where $\beta_{e}=\left(T_{e} / m_{e} c^{2}\right)^{1 / 2} \sim 0.02, \quad q=\omega_{p e}^{2} / \omega_{c e}^{2} \sim 1 \quad$ is the ratio between the electron plasma and cyclotron frequencies, $k=\omega_{c e} / c$ is the vacuum wavenumber corresponding to $54.5 \mathrm{GHz}$, and $L_{B} \sim 10 \mathrm{~cm}$ is the magnetic field inhomogeneity scale. Quasi-transverse launch of the extraordinary $(\mathrm{O})$ mode is impossible at the fundamental harmonics due to plasma refraction and posses the same low efficiency at the second harmonic as the fundamental O mode. Fortunately, the fundamental X-mode 
may be effectively absorbed while propagating quasilongitudinally along the magnetic field at large enough longitudinal refractive index $N_{\|} \sim \beta_{e}^{-1 / 3}$, the total optical depth is then [4]

$$
\tau_{0}^{\mathrm{X}-\text { mode }} \approx \frac{8}{\sqrt{\pi}} \beta_{e}^{1 / 3} q^{2 / 3}(1-q)^{3 / 2} k L_{B} \sim 10 .
$$

However, the quasi-longitudinal launch of waves with high-enough $N_{\|}$is physically impossible at the GDT conditions. The solution proposed is based on a peculiar effect of radiation trapping in an inhomogeneous magnetized plasma column. Under specific conditions oblique launch of gyrotron radiation results in extraordinary mode propagating longitudinally in a vicinity of the cyclotron resonance, what provides effective single-path absorption of the injected rf power. The physics of the radiation trapping may be understood as following. A wave beam injected obliquely from a vacuum posses $N_{\|}<1$ which is nearly constant of the plasma-vacuum boundary. During propagating in plasma the longitudinal refractive index increases as

$$
\Delta N_{\|}^{2} \approx \Delta \varepsilon_{-}\left[\left(\cos ^{2} \theta+\varepsilon_{\|}\right) /\left(\varepsilon_{-}+\varepsilon_{\|}\right)\right]_{\text {at injection point }},
$$

where $\varepsilon_{-}=1-\omega_{p e}^{2} /\left(\omega-\omega_{c e}\right), \quad \varepsilon_{\|}=1-\omega_{p e}^{2} / \omega^{2}$, and $\Delta \varepsilon_{-}$is variation of $\varepsilon_{-}$along the radiation path, $\theta$ is the wave propagation angle. Evidently, if $\left|N_{\|}\right|>1$ at a plasma border, then radiation cannot escape the plasma volume at least as a geometrical-optics ray. A ray is reflected back to the plasma core, and propagates towards the electron cyclotron resonance (ECR) where both $\varepsilon_{-}$and $N_{\|}$are increasing. Finally the ray reaches the vicinity of the ECR with $N_{\|} \sim \beta_{e}^{-1 / 3}$ sufficient for a single-pass absorption. Note that due to increasing $\varepsilon_{-}$ the trapping does not occurs if the injection port is close enough to the ECR surface. Note that the whole effect of trapping is essentially three-dimensional, so it requires at least ray-tracing modeling in a realistic geometry.

\section{NUMERICAL MODELING}

Below microwave radiation propagating in weakly inhomogeneous axisymmetric plasma is described within a ray tracing model for an axisymmetric mirror trap explained in more detail in [5]. Ray-tracing calculations have been performed for the realistic distribution of the confining magnetic field $B_{z}(z, r)$ and $B_{r}(z, r)$. The distributions of electron density and temperature in the GDT device are approximated as

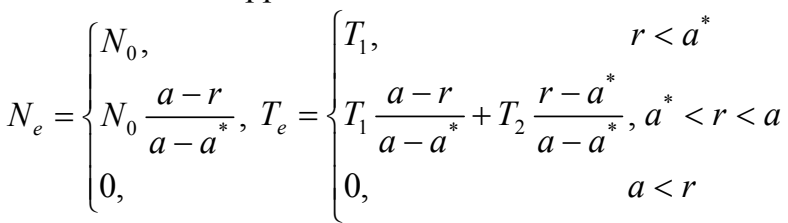
where $a(z)$ is the outer radius of a plasma cord, $a^{*}(z)$ is a size of the plateau of a radial profile, $N_{0}$ is the central density which varies in the range $(0.5 \ldots 5) \cdot 10^{19} \mathrm{~m}^{-3}$, $T_{1}=150 \mathrm{eV}, T_{2}=25 \mathrm{eV}$. The transverse dimensions of the plasma cord may be obtained from conservation of the magnetic flux through the area across the trap axis, $a^{2}(z) B(z, 0) \approx$ const, the same relation holds for $a^{*}(z)$. In the trap center $a=13 \mathrm{~cm}$ and $a^{*}=8 \mathrm{~cm}$.

The ray-tracing model allows us to investigate numerically a number of optimized ECRH scenarios based on the proposed mechanism of wave trapping ${ }^{7}$. In the following we describe the most efficient geometry that was finally used for a hardware design. In the example shown in Fig 1. (left) one can see how a set of rays may be splitted into trapped and untrapped fractions depending on the initial launching angle or the bulk plasma density. In Fig. 2 (right) we demonstrate the effect of bulk (central) plasma density on ray trapping. Note that all trapped rays are $100 \%$ absorbed.

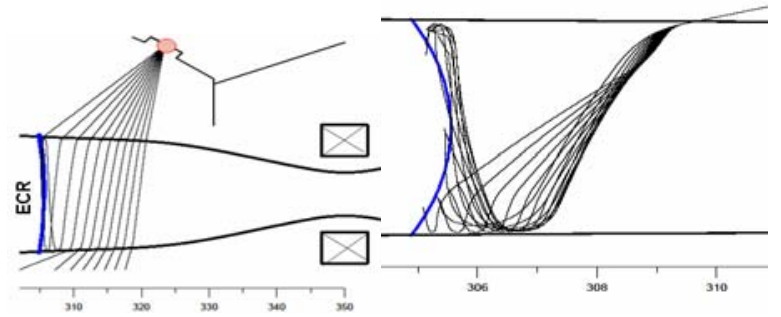

Fig. 1. Left-geometric-optical rays for a set of launching angles $15 \ldots 70^{\circ}$. Bulk plasma density is $1.5 \cdot 10^{19} \mathrm{~m}^{-3}$. Right rays launched with the same angle $55^{\circ}$ for a set of plasma densities in the range of $N_{0}=(0.5 \ldots 2.5) \cdot 10^{19} \mathrm{~m}^{-3}$

Modeling shows that trapping is possible in a sufficiently wide range of plasma densities and for various density profiles corresponding to various experimental conditions. The most important results are summarized in Fig. 2 where the trapping regions are mapped in the plasma density - launching angle diagram. Here we consider three possible positions for the last mirror shown in the inset. After some discussion the "launch 1" point was chosen for the reference design presented below. Correspondingly, this geometry allows operating in the density range $(0.5 \ldots 2.5) \cdot 10^{19} \mathrm{~m}^{-3}$ using a $50 \ldots 55^{\circ}$ angular window.

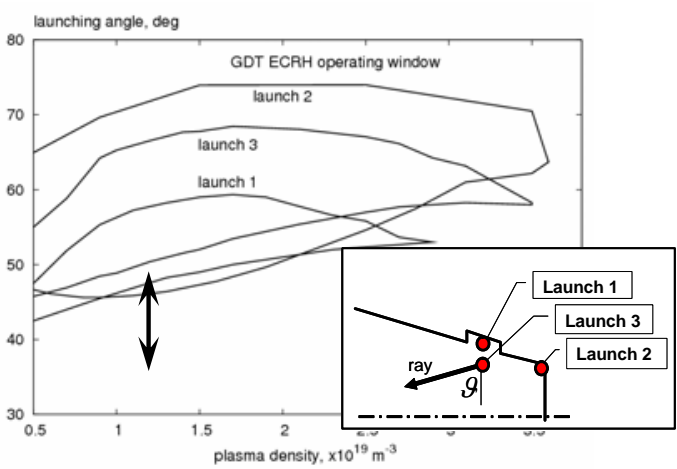

Fig. 2. Operating windows in angle-density plot for tree positions for the ECRH launcher

\section{DESIGN AND CONSTRUCTION}

The ECRH system designed for the GDT device consists of two $54.5 \mathrm{GHz}, 400 \mathrm{~kW}$ gyrotron modules (Buran-A type) operating independently. Each module is equipped with a waveguide transmission line and a launcher. Each transmission line includes a matching optical unit (MOU) to prepare a Gaussian microwave 
beam with parameters suitable for transmission, a corrugated $\mathrm{HE}_{11}$ waveguide (inner $\varnothing 63.5 \mathrm{~mm}$ ) and three $90^{\circ}$ miter bend units. One of these miter bends is just a plane reflector, another one is combined with transmitted and reflected microwave power monitors, and the third one is combined with a polariser to provide microwave beam polarisation optimal for launching and absorption into the plasma column. The total length of the waveguide line is about $31 \mathrm{~m}$. The system provides a fundamental harmonic X-mode Gaussian beam with a radius of $15 \mathrm{~mm}$ at the plasma boundary.
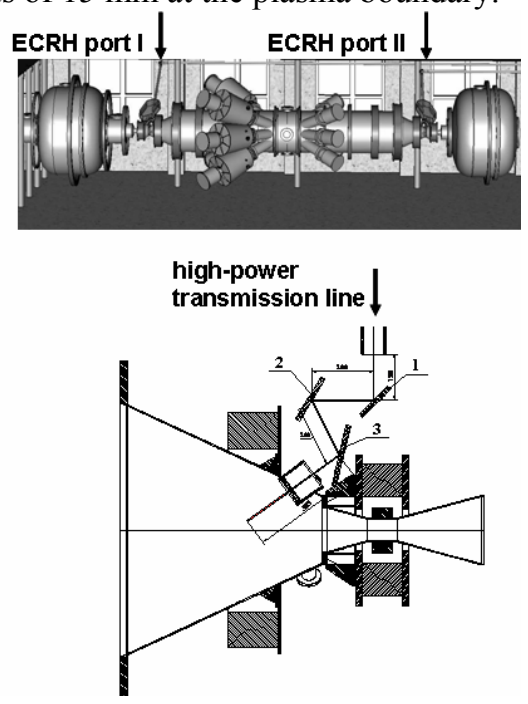

Fig.3. Top - overview of the GDT facility and positions of the ECRH ports. Bottom - schematic of one of the ECRH launchers. Mirror number 1 is plane; mirrors 2 and 3 are parabolic focusing

\section{CONCLUSIONS}

An auxiliary ( 2 x 400) kW 54.5 GHz ECRH system is now under construction at the GDT device in the BINP. The gyrotrons have already been successfully tested in 300 microsecond operation. This system can provide essential enhancement of the electron temperature in GDT up to $300 \ldots 400 \mathrm{eV}$. According to computer simulations, in this temperature range a GDT like neutron source is quite attractive in comparison with accelerator based systems. The design of the proposed ECRH launching system is shown in Fig. 3.

Finally we would like to mention another very promising application of ECRH in GDT which is the creation of a hot electron population for improved confinement. This topic is a matter of on-going research.

\section{REFERENCES}

1. V.V. Mirnov, D.D. Ryutov. // Sov. Tech. Phys. Lett. 1979 , v.5, p. 279.

2. P.A. Bagryansky, A.A. Ivanov, E.P. Kruglyakov, A.M. Kudryavtsev, Yu.A. Tsidulko, A.V. Andriyash, A.L. Lukin, Yu.N. Zouev//Fusion Eng. Des. 2004, v. 70, p. 13.

3. M. Bornatici et al.// Nucl.Fusion .1983, v. 23(9), p. 1153.

4. E.D. Gospodchikov. E.V. Suvorov// Radiophys. and Quantum Electronics. 2005, v. 48 (8), p. 641.

5. E.D. Gospodchikov, O.B. Smolyakova, E.V.Suvorov // Plasma Physics Reports. 2007, v. 33 (5), p. 427.

Article received 18.09 .12

\title{
СИСТЕМА ДОПОЛНИТЕЛЬНОГО ЭЦР-НАГРЕВА ДЛЯ ГАЗОДИНАМИЧЕСКОЙ ЛОВУШКИ
}

\author{
А.Г. Шалашов, Е.Д. Господчиков, О.Б. Смолякова, П.А. Багрянский, В.И. Мальгин, М. Тумм
}

Обсуждаются физические аспекты и возможные параметры новой системы дополнительного ЭЦРнагрева для газодинамической магнитной ловушки ГДЛ (ИЯФ, Новосибирск). При использовании излучения двух 400 кВт / 54.5 ГГц гиротронов можно ожидать повышения температуры электронов до $250 \ldots 350$ эВ и улучшения времени удержания ионов. Трудности, связанные с невозможностью использования традиционных схем ЭЦР-нагрева в геометрии ГДЛ, предлагается преодолеть за счет эффекта захвата излучения, вводимого из вакуума в виде необыкновенной волны под определенным углом, в трехмерно-неоднородной магнитоактивной плазме.

\section{СИСТЕМА ДОДАТКОВОГО ЕЦР-НАГРІВУ ДЛЯ ГАЗОДИНАМІЧНОЇ ПАСТКИ}

\section{А.Г. Шалашов, О.Д. Господчиков, О.Б. Смолякова, П.А. Багрянський, В.І. Малигін, М. Тумм}

Обговорюються фізичні аспекти і можливі параметри нової системи додаткового ЕЦР-нагріву для газодинамічної магнітної пастки ГДП (ІЯФ, Новосибірськ). При використанні випромінювання двох 400 кВт/54.5 ГГц гіротронів можна чекати підвищення температури електронів до $250 \ldots 350$ еВ і поліпшення часу утримання іонів. Труднощі, пов'язані з неможливістю використання традиційних схем ЕЦР-нагрівання в геометрії ГДП, пропонується подолати за рахунок ефекту захоплення випромінювання, що вводиться 3 вакууму у вигляді незвичайною хвилі під певним кутом, в тривимірно-неоднорідній магнітоактивній плазмі. 